between the dorsal spines on the first three abdominal segments.

On the 8 th abdominal segment is a single median stout short spine, not so long as those in tront, but deeply cleft or forked at the end, each fork acute and diverging from its mate. Around the base of the spine are about sixteen pale flattened circular smooth warts.

Suranal plate subtriangular, apex much rounded, with about a dozen solid thick black tubercles, each giving rise to a short minute seta; they are mostly collected around the end of the plate. A lateral reddish line. Thoracic legs stout, pale, black at the sutures between the joints. Abdominal legs reddish below, dark on the planta. Under side of the body speckled with fine oval setiferous pale warts. Anal legs large, their sides triangular in shape, bright yellow, the lower edge or plantar region shining jet-black. Spiracles pale sienna brown.

Length $77 \mathrm{~mm}$; thickness $15 \mathrm{~mm}$.

Described from a blown specimen from Natal, received from Staudinger and Bang-Haas.

\section{UROTA SINOPE IVestwood.}

Larva. - Described from a blown example from Natal received from Messrs. Staudinger \& Bang-l Iaas. Head large round smooth, surface dull brown-black, not polished, unarmed. Body cylindrical, neither humped or conspicuously tuberculated. A prothoracic plate on each side bearing a pair of pale setae which are short, slender, arising from an inconspicuous flattened tubercle (not easily detected in a blown example) situated as are all the thoracic and abdominal ones on the hinder edge of the segment. On abdominal segments 1 to 7 are two widely separated rows of minute flattened tubercles giving rise to a pair of slender flattened setae which are pale at the base and darker toward the tip; there is also a lateral row (there are in all as in the family in general 3 rows of tubercles on each side of the body). The setae are in groups of from 2 to 5 , each seta arising from a separate minute secondary tubercle; the setae are about $\frac{1}{6}$ as long as the body is thick. On the Sth abdominal segment there is no median tubercle, but 2 groups of + rather long setae each arising from minute separate bases; they are white, slender, curred; each group situated not far from the median line. On the side of the body below and behind the spiracle, though close to it, is a group of 3-4 setae. Ont the gth segment are 3 sets of similar setae arranged as on the Sth segment; those on the sides below the spiracles are longer than those abore. Spiracles black. Thoracic and abdominal legs blackish. Anal legs of moderate size. Suranal plate with three groups of rather long setae on each side; the plate rounded, surface convex and a little corrugated. Base of abdominal legs $(1-4)$ reddish. The slin rough, finely granulated. Thoracic segments $2-3$ and abdominalones with a transverse band of coarse pale yellowish flattened gramulations. smooth. the band on the side widening and surrounding the spiracles. Length $55 \mathrm{~mm}$., thickness 9 mm.

\title{
SOME INSECTS OF THE HUDSONIAN ZONE IN NEW MEXICO.- VI.
}

HYMENOPTERA APOIDEA. II.

BY T. D. A. COCKERELL.

The following, taken on the top of the Las Vegas Range at the end of June,
I $90 \mathrm{I}$, are additional to the previous list. (Psyche, Feb. 1901, p. 163.)

Bombus appositus, Cresson. I $q$. Anthophora cardui, Ckll. I d. I was surprised to find this at such an altitude. 
It is doubtless the same insect which has been reported from New Mexico as A. smithii, Cresson, and I am not positive that it should be separated from that species.

Megachile willushlitlla (Kirby). 28 . This European species has not hitherto been reported from America, but the males before me agree exactly with examples from Mr. Friese, collected at Lugano, June 25, I88.4. The insect resembles a good deal the male of $M /$. latimamus, but is smaller, with the four hind legs practically normal, and the anterior femora have a short oblique keel on the outside near the apex. I have other New Mexico specimens, one from Las Vegas, June 6 (N. E. Cochran); six from the Rio Ruidoso, collected by C. H. T. Townsend. Of these last, three were collected July 29, at $6700 \mathrm{ft}$., on flowers of I'icia aff. fulchella ; one Alig. 3, $7500 \mathrm{ft}$, on Verbenta mutdougali; one, July z2, 6goo ft., and one July $25,6500 \mathrm{ft}$, the last two on MONardit strictu. The only objection to regarding these males as veritable zoillughbiclla. rests in the fact that I have nothing American agreeing with the female of that species. The species which comes nearest to it, and looks like the female of the just mentioned males, is $1 \%$ monudarum, CkJl. This differs from a $q$ willughthiclla sent by Mr. Friese, in the black hair of the mesothorax, the pure white hair of the pleura and the ventral scopa not being black on the last two segments.

Ostria faccta, Cresson. 2 \&. In fresh examples there is a good deal of black hair on the dorsum of the apical half of the abdomen, not mentioned by Cresson.

Osmia inurbana, Cresson. I $\mathcal{Z}$. Length $7 \frac{1}{2}$ millim. The specimen differs from typical inurbum in having the sixth abdominal segment only slightly emarginate; I was at first inclined to treat it as a distinct species, but a series of inurbum before me is so variable, that I hesitate to propose any segregation. The insect is also very like $O$. albizentris, but differs specifically in the bronder face, perfectly black antennae, sisth abdominal segment not margined with testaceous, apical segment strongly bidentate, and the hind tarsi much broader, the first joint being twice as broad, and edged within by a short fringe of bright orange-fulvous hair. It is also very near to the European $O$. arrsicolor. O. imurbana is new to New Mexico.

Prosopis z'arifrons, Cresson. I 8 .
Prosopis busalis, Smith. I 9.
Colletes nigrifrons, Titus. I 9 . New to New Mexico. Differs from a cotype received from Mr. Titus in having no black hair on scutellum, but is clearly the same species.

\section{$\checkmark$ Andrena bivtwelli, n. sp.}

9. Length about $10 \mathrm{~mm}$., black; head and thorax clothed with long. erect, grayish-white hair; black on rertex and hind part of checks; long, white and curled on each side of metathoras, where it forms a scopa filled with yellow ish-white pollen. llead ordinary; facial quadrangle bronder than long; area behind ocelli punctured; front below ocelli coarsely strigose; clypeus microscopically 
tessellate, with numerous large punctures, wanting in the middle line; process of labrum broad, emarginate; antennae fairly long, flagellum ferruginous benenth towards the tip; third antennal joint longer than ++5 . Mesothorax microscopically tessellate, quite dull, punctured; hasal area of metathorax triangular, not bounded by a ridge, microscopically tessellate with a few irregular basal raised lines; tegulae shining dark brown; wings smoky, nervures piceous, stigma ferruginous edged with piceous; second submarginal cell little narrower above than below, third submarginal narrowed fully half to marginal. Legs black, small joints of tarsi dull ferruginous; hair of legs mostly pale, a black tuft on hind knees, basal joint of hind tarsi broad, with dark brown hair; abdomen oval, convex, shining, microscopically tesseliate, with only minute very sparse punctures; first segment fringed at sides and apex with long but not dense white hair ; remaining segments nearly naked, with some white hairs at sides, tending slightly towards band-formation; fimbria at apex pale brownislogray.

I $\&$, June 27. It is named after Mr. F. J. Birtwell, the clever young ornithologist who was accidentally killed on the Upper Pecos the day following the capture of this insect. A. birtwelli appears to be related to $A$. lapponica, A. frigida and A. conz'cua, but is not identical with any of them.

\section{$\checkmark$ Andrena merriami, n sp.-}

q. Length about $10 \frac{1}{2} \mathrm{~mm}$., black; pubescence all black except on mesothorax, scutellum and postscutellum, where it is pale ochraceous. Facial quadrangle broader than long; vertex dull, minutely roughened; clypens microscopically tessellate, strongly punctured, the punctures sparse in the median line; antennae short, black, hagellum slightly brownish beneath; first flagellar joint a little longer than the next two together; process of labrum with sloping sides and emarginate apex; mesothorax dull, minutely roughened; enclosure of metathorax ill-defined, minutely. roughened; sides of metathorax with black hair ; tegulae very dark brown ; wings smoky, nervures and stigma piceous; third submasginal cell long, narrowed more than half to marginal; abdomen shining, microscopically tessellate, with sparse punctures at the bases of the hairs; no hair bands, except black ones on the ventral surface; fimbria abundant and black.

One 9, June 27. Named after Dr. C. H. Merriam, in recognition of his valuable work on the Hudsonian zone. $A$. merriami is something like A. anograe in miniature. In Schmiedeknecht's tables of palaearctic species, it runs to $A$. albopicta, Rad., but is not the same.*

\section{Halictus rirgatcllus, n. sp.- - .}

Length about $8 \mathrm{~mm}$; head and thorax very dark green; abdomen black with broad white hair bands on the apical margins of the segments; fimbria ochraceous. Facial

* The following species, closely allied to A. morriani, may be made known at the preseut time:-

Andrent washingtoni, 11 . sp.- \&. Lung, $10 \frac{1}{2} \mathrm{~mm}$.; differs from merriami as follows: hair of metathorax and upper part of pleura (as well as mesothorax etc.) pale ochraceous (black on lower part of pleura, and pectus), the abundaut curled floccus at base of hund legs beneath white, but just anterior to it a tuft of coarse black hairs. strongly coutrasting; hair about mouth more or less pale (otherwise the lyair of head is all black); first abdominal segment, and middle of second, with long pale hairs; process of labrum short and broad, strougly emarginate, one might say binodose; tegulae lighter brown; stigma dark ferruginous; third submarginal cell less produced apically; tibial spurs light ferruginous; small joints of tarsi, and pubescence of basal joints towards end, ferruginous.

Hab.- Olympia, Washington State, June 2, 1595. (Trevor Firtcaid.) 
quadrangle ahout square; clypeus rather strongly produced; antennae black, the thagellum taintly brownish beneath towards apex; mesothorax shining, densely and strongly punctured; basal area of metathorax coarsely wrinkled; tegulae very pale brown; wings smoky, nervures very dark brown, stigma lighter brown; hind spur of hind tibia pectinate.

Allied to $H$. fasciatus (as understood by Robertson), but larger, with the anterior knees and tibiae wholly black, the wings and their nervures much darker, the third submarginal cell much broader above (being narrowed less than half to marginal), the abdomen quite without an aeneous lustre, and with the bands snow-white. In both species the first flagellar joint is very short, hardly longer than the second. $H$. rivgatellus is distinguished from H. trizonatus by its dark nervures and clense punctures.

\section{Falictus hemimelas, n. sp.--}

q. Length about 7 mm. ; head and thorax very dark olive green, legs and abdomen black, the latter with a purple tint about the middle of the second and third segments. Head somewhat elongated, facial quadrangle longer than broad; clypeus prodnced, black. with large sparse punctures; front clull, with excessively close punctures; antennae black, flagellum slightly brownish towards end; scape curved, long, almost reaching anterior ocellus; Hagellum short; mesothorax mimutely tessellate, with distinct punctures, not very dense in the middle; base of metathorax rugulose, not bordered by a sharpedge; tegulae shining piceous: wings smoky, nerr. ures and stigma very datr brown; third submarginal cell short and high, narrowed less than half to marginal; legs with silverywhite hair ; hind spur of hind tibia pectinate with only two well-formed teeth; abdomen shining. with extremely minute punctures, apical portions of the segments minutely transversely lineolate; elongate subtriangular white hair-patcless at lateral bases of segments 2 to 4 . much in the manner of $H$. pectoraloides; a good many white hairs on abdomen beneath and at apex; fimbria pale brownish.

One 9 , June 29.

\section{Halictus dasiphorac, n. sp.-}

f. Length about $7 \mathrm{~mm}$., general appearance of the last species, but wholly black, and the abdominal hair-patches are less pronounced, being more merged in the general pale pruinosity, especially after the second segment. The orbital margins on the inner side are not far from straight, whereas in $H$. hemimelas they are quite strongly concave. The form and sculpture of the head, the form of the antennae, and the sculpture of the mesothorax and metathorax, are about the same in the two species, but in dasifhorat the enclosure of the metathorax is longer, and the flagellum is fulvous beneath except at the apex. The wings of dasifhorae are $\mathrm{dusky}$ as in hemimelas, but the nervures and stigma are rather pale brown; the venation is about the same in the two species.

5 females. June 27 .

H. dasiphorat cannot be the $q$ of $H$. firaltus, on account of its dusky wings with lighter nervures. It differs at once from pectoralis by the granulose (not ridged) base of metathorax, and more produced clypeus; from gracilis by the granulose (not cancellate) base of metathorax and dusky wings: from sulobscurus by its larger size, dusky wings, second submarginal cell little narrowed above, etc.; from similis by its smaller size, third submarginal cell longer than 
second on radial nervure in (similis they are equal), and in the narrower head.

Halictus atganus, n. sp.-

q. Length about $6 \mathrm{~mm}$., brassy green, including the abdomen; legs black. This is very like 11 . ruidosensis, and has the more or less coppery or bressy tint on the supra clypeal area, but it is certainly a distinct species, presenting the following distinctive characters:- inner orbital margins less concave; hasal area of metathorax much longer, and irregularly cancellate all over, especially at the sides; abdonen green (occasionally this is scarcely perceptible), with the first segment minutely transversely lineolate, with fuite numerous if minute punctures; third submarginal cell narrower above. In both, the hind spur of hind tibia is pectinate with tew teeth. The wings are faintly dusky, and the stigma is light hrown.

$$
7 \text { females, June } 27 .
$$

\section{NEUROPTEROID INSECTS.}

\section{BY NATHAN BANKS.}

Both of the two Neuropteroid insects collected at the top of the Las Vegas range in New Mexico appear to be undescribed; both belong to genera having many species in northern and boreal regions. One belongs to the Neuroptera, the other to the Trichoptera.

\section{Hemerobitde.}

\section{Hemerobius cockerelli $\mathrm{n}$. sp.}

Ilead pale yellowish, darker across base of clypeus; antennae pale yellowish, not banded; thorax pale yellowish, with a broad brown stripe on each side, not as plain behind as on the prothorax ; abdomen pale at base, darker beyond; legs pale; fore-wings pale brown, with many white spots through the middle region, these white spots margin similar spots on the otherwise brown veins, and they are arranged in transverse series; there are a few of these spots beyond the outer gradate series. A darker brown band across both series of gradate series, and a large spot at the connection between the cubitus and postcubitus. Hind wings hyaline, yeins brown. Around the margin of both pairs there are many brown dots, one between and one at the end of each veinlet; there are no white spots on the margin. The wings are moderately narrow, not much swollen on costa at base; three sectors, the first branch of the first connected back to radius twice; the postcubitus bent toward the cubitus, so that the connecting veinlets are of unequal length. Male appendages with a lower and a median projection, the latter bifid at tip.

Length, ro $\mathrm{mm}$.

One specimen from top of Las Vegas range, New Mexico.

\section{LAMTOPHILIDAE.}

\section{Asynarchus costalis n. sp.}

Face yellowish; palpi yellowish, slender; vertex reddish yellow, ocelli small, posterior and anterior tubercles subequal in size; antennae long and slender, reaching beyond end of wings, yellowish on base, darker beyond, the basal joints about one-half their diameter apart, and as long as the face, the outer and inner sides each marked with a broad brown stripe; legs slender, pale yellowish, spines black, spurs 1-3-4, first tarsal joint of $\delta$ long, few spines on tibia $I$, one at tip of fenur I.; thorax with a brown stripe each side. Fore-wings quite long, rounded at tip and on apical margin, the surface minutely granulate, sparsely clothed with short yellow hair, black hair near posterior margin; the basal costal area is hyaline, beyond and behind is brown, with many small pale spots; larger pale spots in bases of all apical celis 
except the first, a long one in base of first subapical, a spot on thyridium before the posterior anastomosis and reaching into cell, and a spot in the thyridial cell still nearer the base; veins dark brown. The first and fifth apical cells extend but little basad of the anastomosis; the discal cell is a litle longer than $\mathrm{jts}$ pedicel; the veins at posterior anastomosis are disjointed. The hind wings are hraline, with brown veins, the fourth apical cell nearly as broad at the second, a dot in the base of the third.

Length, ${ }_{3} \mathrm{~mm}$.

Two specimens from top of Las Vegas range, New Mexico.

\title{
LIFE HISTORIES OF NORTH AMERICAN GEOMETRIDAE. - XYYIII.
}

\author{
BY HARRISON G. DYAR, WASHINGTON, I). C.
}

Eucrostis viridifennatu IIulst.

Egg. Elliptical, disk-like, flattened concave above and below with sharp edges, one end a little more rounded pointed than the other, narrower, neither perceptibly truncate or depressed. Smooth olivaceous green, shining, with small, narrow and obscure retieulations. Size $.8 \times 6 \times .3 .5 \mathrm{~mm}$.

Stage 1. llead rounded bilobed, not shining yellowish ochraceous; width about $\cdot 3$ mm., ocelli black. mouth brown. Body with a subdorsil point on joint z anteriorly, the segment slightly collared; else smooth, cylindrical, moderately elongate, nomal. Segments faintly several-anmulate, the incisures not depressed. A slight rounded stigmatal elevation, most visible on joints 5, 6 and 10 Greenish white, a diffuse red-brown dorsal line, narrowed to ob-olescence at the ends. Tubercles and setac very small and obscure, the latter very short, black with enlarged tips. Skin minutely shagreened granuliur.

Stage II. Head bilobed, the lobes produced into rertical, conical horns, that before; yellowish, granular, ocelli black. Body cylindrical, uniform, segments not incised, finely granular; a slightly elevated dormal line. Feet normal, the anal ones with large granular plates. Yellowish white, tinted with brown, the granules and subdorsal line whitish, the anal plates pale edged. Conical horns on joint a concolorous, grantuar. Thoracic feet appressed. No marks, no setae nor tubercles. Anal plate pointed behind.

Stage 1Il. Head strongly conically bilobed, held obliquely forward, pale greenish yellow, granular. Body as before, the cones on joint 2 smaller than the head lobes but similar. body green, the linear, subdorsal, whitish raised line looped up a little anteriorly on the segments. Pale whitish yellow with a diffuse brown dorsal band obsolete at the ends. Anal plate pointed; anal teet extended laterally with large plates.

Stage IIr. llead granular roughened, the lobes protuced into conical horns, greenish yellow, apices brown, a blackish shade on the outer side of lobes; width s mm. Body. as before, light yellowish green with a faint and diffuse brown dorral line, obsolete at the ends. Subdorsal raised line as before, whitish, obscure. Skin densely pale granular. The long pointed anal shield exceeds the ratler high anal leg shields. A dark brown shade subventrally on joint 12 . Thoracic feet faintly reddish shaded.

Stage ir. Head gramilar, the high, erect, pointed lobes projecting as far as half the height of the head; whitish green on face. lobe's and sides brown shaded, with a few blackish dots; witth $1+$ mm. Body slender, green, angular ac the joints when bent, the cones on joint 2 smaller and slenderer than 

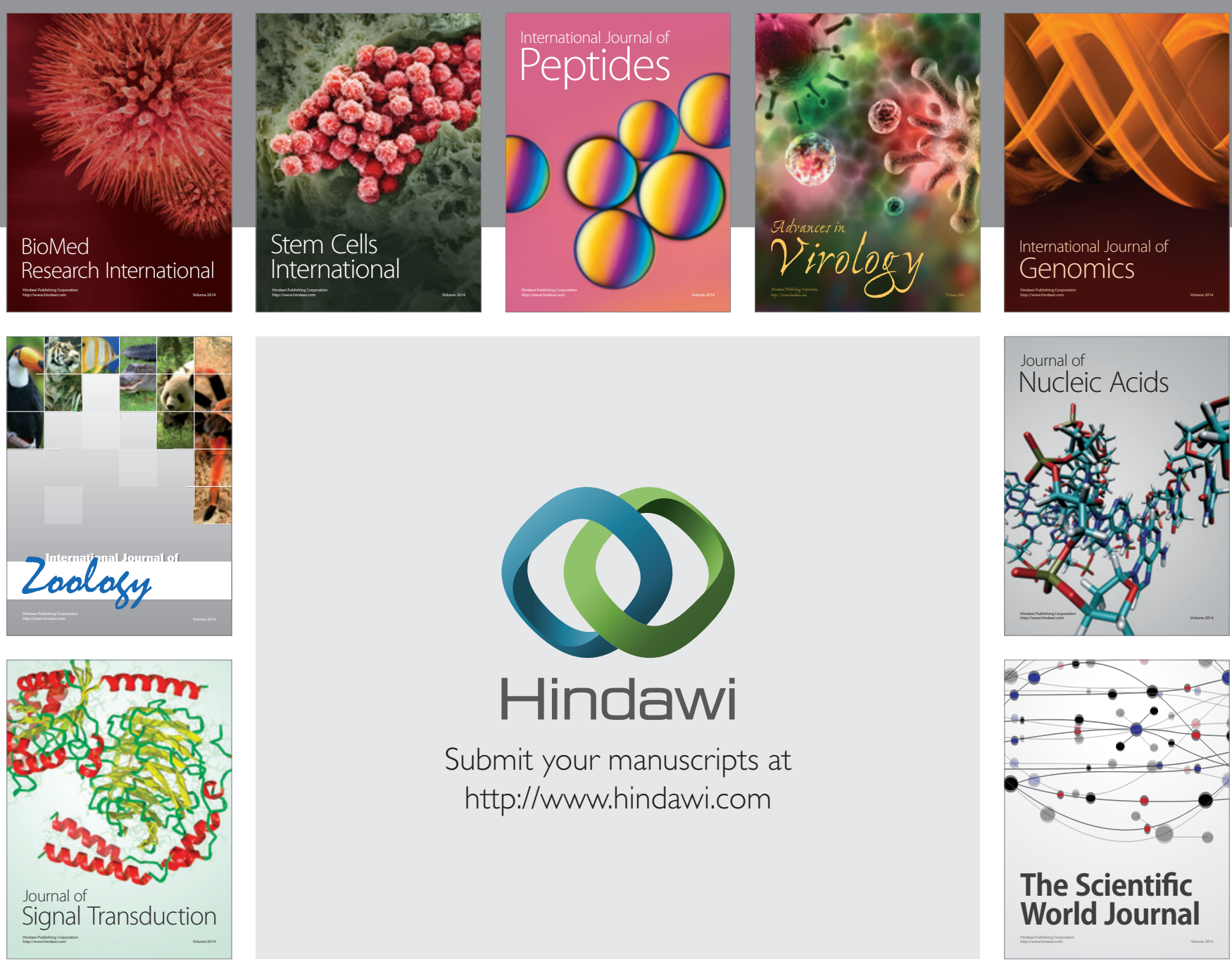

Submit your manuscripts at

http://www.hindawi.com
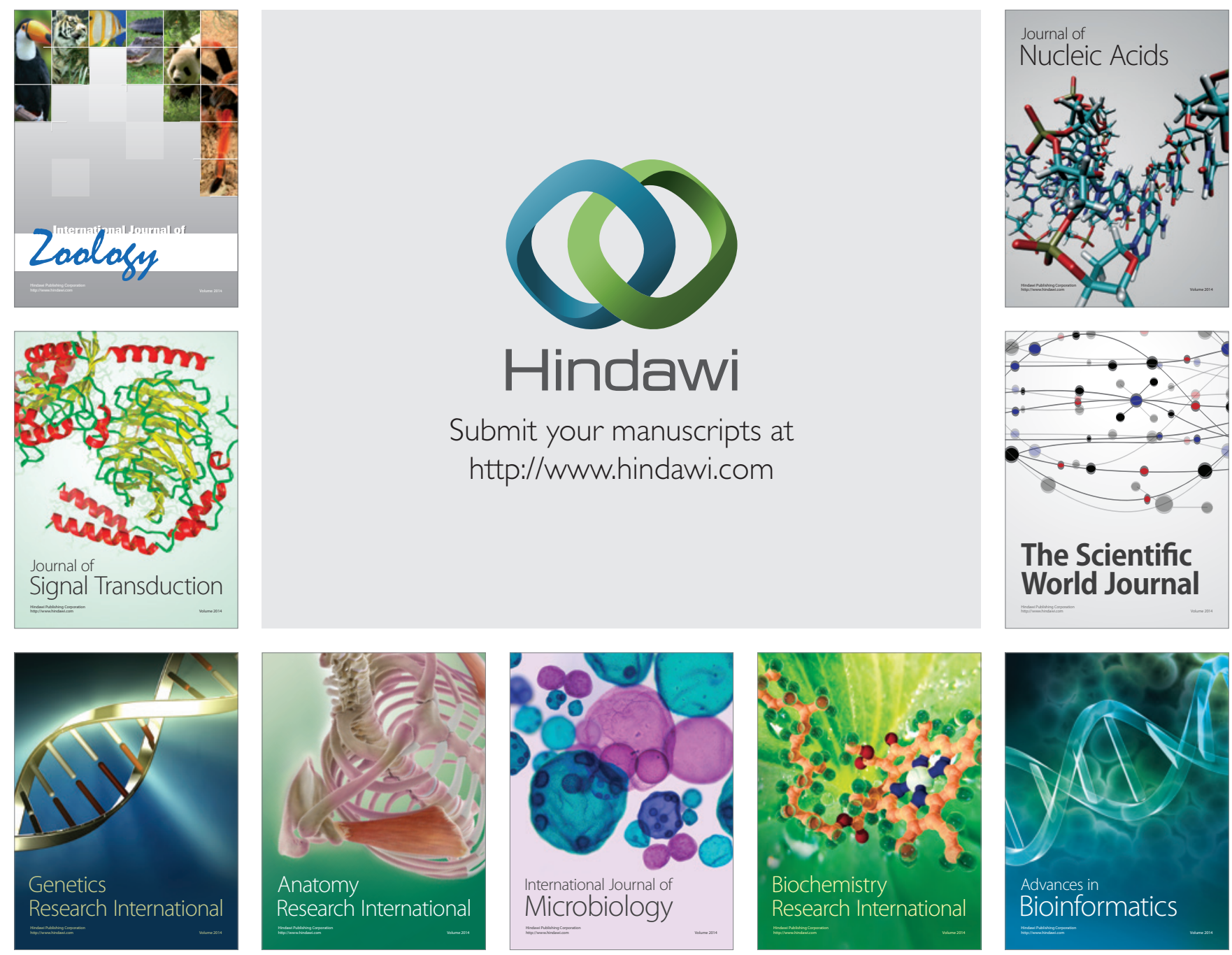

The Scientific World Journal
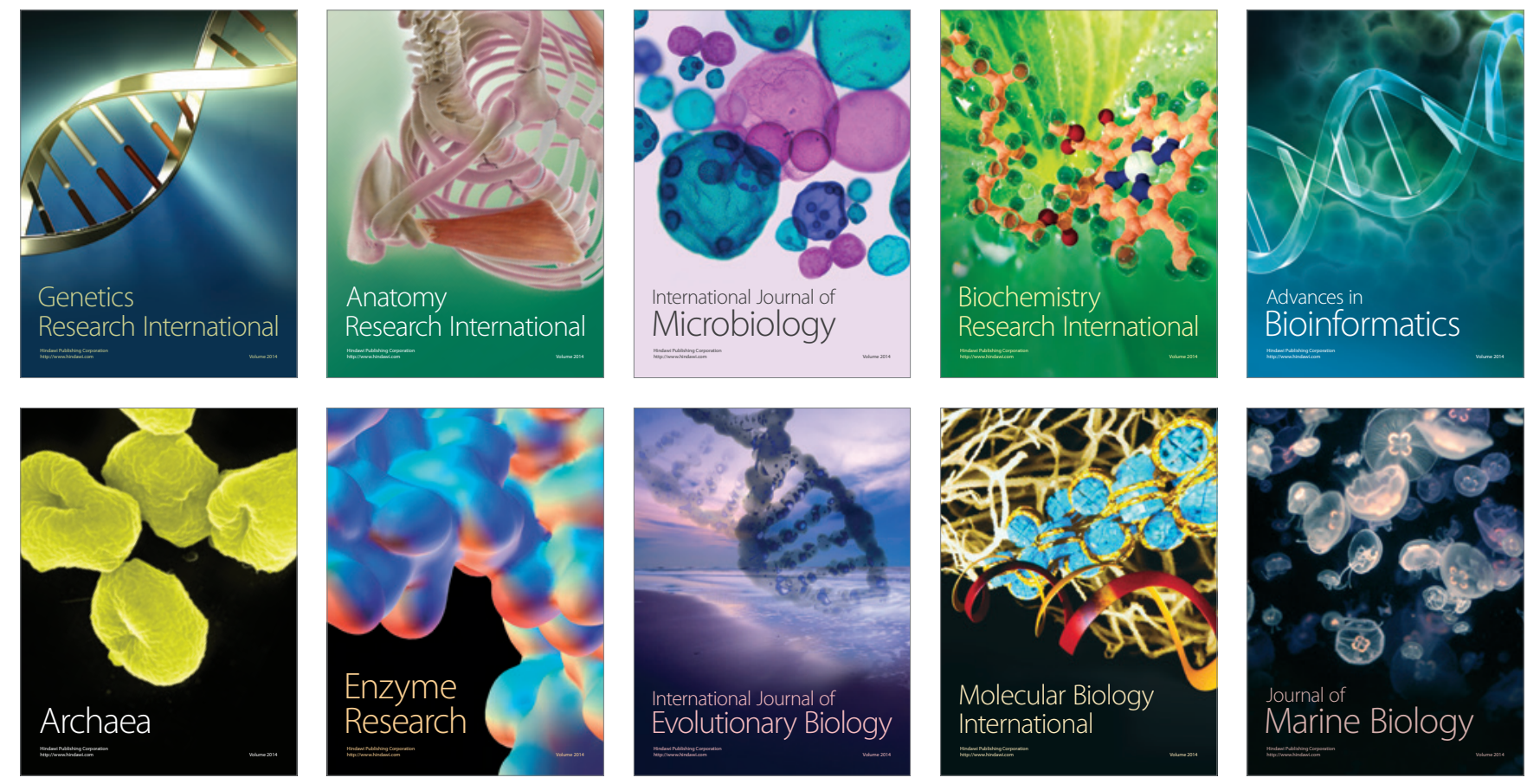